\title{
IMPLEMENTASI REWARDDAN PUNISHMENT TERHADAP PENINGKATAN KOSA KATA BAHASA INGGRIS DI BINTANA RESEARCH AND LITERACY SHELTER INDONESIA
}

\author{
Zaenol Abidin, Gina Romadhona, Vera Yuli Andini, Muhammad Faiz \\ Universitas Islam Negeri KH. Achmad Siddiq Jember \\ zaenolabidin530@gmail.com,ginaromadhon134@gmail.com,verayuliandini01@gmail.com,gen_cang@ya- \\ boo.com
}

\begin{abstract}
Abstrak:
Tujuan penelitian ini adalah untuk mendeskripsikan penerapan metode reward dan punishment dalam peningkatan kosa kata bahasa Inggris serta menggali informasi mengenai kelebihan dan kekurangan metode reward dan punishment. Metode penelitian dalam kajian ini adalah metode deskriptif. Teknik pengumpulan data dilakukan dengan observasi, wawancara, dan dokumentasi. Hasil penelitian ini mendapati bahwa penguasaan kosa kata bahasa Inggris peserta didik meningkat. Selain itu tingkat keyakinan dan kepuasan siswa dalam proses pembelajaran semakin baik. Praktik pemberian reward dan punishment disesuaikan dengan kebutuhan siswa. Reward berupa hadiah kerajinan tangan, pujian, dan nilai. Sedangkan punishment berupa pengulangan materi dan tidak mendapatkan hadiah. Kelebihan dari metode ini adalah menumbuhkan rasa kompetitif dan memotivasi belajar secara maksimal. Sedangkan kekurangan dari metode ini berupa biaya yang harus disiapkan untuk memberikan hadiah serta terfokuskan pada siswa yang aktif saja, sebaliknya menjadi beban bagi siswa yang malas dan memiliki mental yang lemah.
\end{abstract}

Kata Kunci: Metode, reward dan punishment, kosa kata dan bahasa Inggris.

\begin{abstract}
:
The purpose of this study is to describe the application of the reward and punishment method in increasing English vocabulary and to explore information about the advantages and disadvantages of the reward and punishment method. The research method in this study is a descriptive method. Data collection techniques were carried out by observation, interviews, and documentation. The results of this study found that mastery of English vocabulary increased. In addition, the level of confidence and student satisfaction in the learning process is getting better. The practice of giving rewards and punishments is adjusted to the needs of students. Rewards are in the form of handicraft gifts, praise, and grades. While punishment is in the form of repetition of material and not getting a prize. The advantage of this method is that it fosters a sense of competitiveness and motivates maximum learning. While the drawbacks of this method are in the form of costs that must be prepared for gifts and focus on only active students, on the contrary it becomes a burden for students who are lasy and have weak mentality.
\end{abstract}

Keywords: Method, Reward and Punishment, Vocabulary, English

\section{PENDAHULUAN}

Pendidikan di Indonesia dilakukan secara formal dan non formal. Suatu lembaga mewujudkan fungsi dan tujuan pendidikan nasioanal yang telah ditegaskan dalam Undang-Undang Republik Indonesia Nomor 2 tahun 2003 tentang Sistem Pendidikan Nasional Bahwa: "Pendidikan 
Nasional berfungsi mengembangkan kemampuan dan membentuk watak serta peradaban bangsa yang bermartabat dalam rangka mencerdaskan kehidupan bangsa, bertujuan untuk mengembangkan potensi peserta didik agar menjadi menusia yang beriman dan bertakwa kepada Tuhan Yang Maha Esa, berakhlak mulia, sehat, berilmu, cakap, kreatif, mandiri dan menjadi warga negara yang demokratis serta bertanggung jawab".

Pendidikan merupakan aspek yang sangat dibutuhkan dalam mengembangkan wawasan, menemukan kemampuan, dan bekal peserta didik untuk menjadi seseorang yang intelek di masa mendatang. Pendidikan akan memberikan ruang kepada manusia untuk mengenal, mempelajari, mengadopsi serta mengamalkan kemampuan belajar sesuai konsep dan teori dalam kehidupan berbangsa dan bernegara. Terutama generasi muda yang menjadi pemegang tongkat estafet generasi bangsa selanjutnya. ${ }^{1}$

Pendidikan merupakan usaha sadar dan terencana untuk menciptakan suasana belajar dan proses belajar siswa agar aktif dalam mengembangkan potensi dirinya untuk memiliki kekuatan spiritual, keagamaan, pengenalan diri, kepribadian, kecerdasan, akhlak mulia, serta keterampilan yang diperlukan dirinya, masyarakat, bangsa dan negara. Salah satu tugas dan tanggung jawab seorang pendidik atau guru merupakan menjadi pembimbing kepada siswanya baik dalam pembelajaran terlebih lagi dalam pembentukan karakter. ${ }^{2}$

Oleh karena itu, pendidikan sangat dibutuhkan oleh manusia terutama generasi muda yang akan menjadi penerus bangsa dan negara. Selain itu, suksesnya pendidikan tergantung metode pembelajaran yang digunakan oleh pendidik dalam memberikan pemahaman terhadap siswanya baik di dalam pendidikan formal atau non formal.

Metode pembelajaran dapat diartikan sebagai cara yang dapat digunakan untuk mengimplementasikan rencana-rencana yang telah disusun kedalam bentuk kegiatan nyata yang praktis untuk mencapai tujuan pembelajaran yang diinginkan. Terdapat beberapa metode pembelajaran yang dapat digunakan untuk penerapan strategi dalam pembelajaran, salah satu diantaranya ceramah, diskusi, dan sebagainya. Metode pembelajaran adalah cara yang digunakan guru dalam mengadakan hubungan dengan siswa pada saat pembelajaran berlangsung. ${ }^{3}$

Metode pembelajaran adalah cara-cara penyajian materi pelajaran yang dilakukan oleh guru agar terjadi proses pembelajaran pada diri siswa dalam upaya mencapai tujuan. ${ }^{4}$ Upaya penggunaan

\footnotetext{
1 Yunus dan Moch. Hasyim Fanirin, "Penerapan Metode Reward and Punishment dalam Penguasaan Kosakata Bahasa Arab Kelas IV Madrasah Diniyah Takmiliyah Awaliyah Haurkolot, Indramayu” (Jurnal Pendidikan Indonesia, Institut Agama Islam Al Zaytun Indonesia, 2021), 139.

2 Maisah Asmawati, dkk., "Pemberian Reward dan Punishment Terhadap Motivasi Belajar Siswa pada Muatan PPKN Kelas IV SDN Pemepek Kecamatan Pringgarata Tahun Ajaran 2020/2021” Jurnal Inovasi Penelitian, Universitas Mataram, 2020), 1289.

${ }^{3}$ Nana Sujana. Penelitian hasil proses belajar mengajar. (Bandung: PT. Remaja Rosdakarya. 2005), 76

4 Sutikno, M. S. Belajar dan Pembelajaran, (Prospect. Bandung. 2009), 88
} 
metode pembelajaran, guru dapat menentukan teknik yang relevan dengan kebutuhan siswa, setiap guru memiliki taktik yang berbeda antara guru yang satunya dengan yang lain. Metodologi ialah cara menghasilkan dan mengadakan secara sistematis mengenai tingkah laku dengan melihat atau mengamati individu atau kelompok secara langsung. Maka metode ini bisa digunakan untuk mengatahui motivasi siswa dalam belajar. Kegunaan metodologi dapat mengetahui antara lain:

1. Menambah wawasan bagi siswa mengenai peristiwa, gejala atau kejadian yang terjadi dalam limgkungannya atau objek yang diamati.

2. Melatih kecerdasan dan kepekaan siswa terhadap kejadian-kejadian yang ada dilingkungannya.

3. Menanamkan nilai moral pada siswa. Terdapat suatu prinsip yang umum dalam penggunaan metode yaitu prinsip agar pengajaran dapat disampaikan dalam suasana menyenangkan, menggembirakan penuh dorongan dan motivasi sehingga materi pelajaran atau materi didikan itu dapat dengan mudah diberikan kepada peserta didik

Oleh karena itu, metode pembelajaran sangat diperlukan untuk membantu pendidik dalam proses belajar dan mengajar. Salah satu metode yang bisa diterapkan dalam proses pembelajaran yaitu metode Reward and Punishment.

Metode Reward and Punishment merupakan salah satu metode yang bisa dimplementasikan dalam suatu proses pembelajaran. Metode ini terdiri dari dua kata yaitu Reward and Punishment. Reward (hadiah) merupakan sesuatu yang diberikan kepada orang lain karena sudah bertingkah laku sesuai dengan yang dikehendaki. ${ }^{5}$ Hal tersebut bisa disimpulkan bahwa hadiah adalah sebagai alat atau media untuk mendorong, menyemangati, dan meningkatkan prestasi belajar agar sesuai dengan harapan yang diinginkan dalam proses pembelajaran yang dilakukan guru terhadap peserta didik.

Reward merupakan bentuk reinforcement (penguatan) yang bersifat positif. Guru biasanya akan memberikan nilai tambahan bagi siswa yang mampu mengerjakan tugas sebagai reward (hadiah). Reward tidak selalu berbentuk sebagai barang atau materi, bahkan reward bisa juga berbentuk sebagai motivasi bagi siswa. Reward juga dapat berbentuk sebagai pujian bagi siswa yang dianggap berhasil dalam melakukan suatu tugas. Pemberian dan pengimplementasian reward dalam proses belajar-mengajar tentunya dianggap dapat memacu peserta didik untuk bisa belajar lebih giat lagi. Peserta didik akan semakin termotivasi dalam melakukan banyak hal lebih baik lagi. ${ }^{6}$

Oleh karena itu, adanya reward sebagai sebuah metode pembelajaran, tentunya akan menghasilkan sebuah kepuasan yang akan membuat peserta didik merasa senang. Hal tersebut, akan membuat peserta didik mempertahankan perilaku yang memunculkan kepuasan dari hasil usaha yang telah dilakukan. Selain berpengaruh terhadap rasa kepuasan pada peserta didik, reward

\footnotetext{
5 Arikunto, Suharsimi. Penelitian Tindakan Kelas. (Jakarta: Bumi Aksara, 2006), 67

${ }^{6}$ Umi Kusyairy, Sulkipli, meningkatkan hasil belajar peserta didik melalui pemberian reward and punishment Volume. 6 No. 2, September 2018, 84
} 
(hadiah) akan memberikan dorongan kepada peserta didik untuk memicu kompetisi dalam mendapatkan hadiah dari hal-hal yang akan dicapai. Dampak penggunaan metode Reward dianggap penting untuk diberikan sebagai hadiah kepada peserta didik yang mendapatkan pencapaian yang tinggi dalam proses belajar.

Sedangkan, Punishment (hukuman) adalah punishment adalah bentuk reinforcement (penguatan) yang negatif. Punishment atau hukuman juga bisa diartikan sebagai salah satu bentuk tindakan seseorang dalam memberikan atau mengadakan nestapa dan penderitaan dengan sengaja kepada anak yang menjadi asuhan kita, dengan harapan agar penderitaan tersebut betul- betul dapat dirasakan siswa menuju arah perbaikan.

Kita bisa menyimpulkan bahwasanya metode Reward and Punishment merupakan metode yang menggunakan hadiah dan hukuman dalam mengoptimalkan proses pembelajaran. Hukuman juga berarti sebagai penderitaan yang diberikan dengan sengaja oleh seorang guru setelah terjadinya suatu pelanggaran, kejahatan atau kesalahan. ${ }^{8}$ Punishment juga berbentuk sebagai pengulangan kembali pelajaran (remedial) bagi siswa yang tidak dapat mengerjakan tugas yang sudah diberikan. Sebuah hukuman atau punishment dalam lingkup pendidikan dianggap memberikan bentuk perlakuan yang kasar sehingga menimbulkan efek yang berbahaya bagi siswa.

Maka dari itu, ada banyak pendapat yang menyatakan kurang setuju terhadap tindakan punishment dalam dunia pendidikan. Oleh karena itu, pemilihan dan pemberian hukuman bagi pesera didik harus dilakukan dengan hati-hati. Bila terpaksa melakukannya, berilah hukuman yang mendidik dan tidak menyakiti badan dan jiwa. Pemberian hukuman itu harus adil. Makna adil yang benar adalah pemberian hukuman harus sesuai dengan kesalahan yang dilakukan oleh peserta didik. Peserta didik harus faham dan mengerti alasan pemberian hukuman tersebut. Hukuman harus memberikan kesadaran pada anak akan kesalahan yang diperbuat. Jangan sampai bentuk hukuman meninggalkan rasa dendam pada anak tersebut. ${ }^{9}$

Bisa dipahami bahwa seorang guru harus mampu mengenal kebutuhan siswanya. Hal tersebut akan membantu guru memberikan hadiah atau hukuman dalam peningkatan hasil belajar atau pemahaman siswa. Metode Reward and Punishment ini bisa diimplementasikan pada berbagai macam mata pelajaran di lembaga pendidikan formal atau non formal. Salah satu pelajaran tersebut adalah mata pelajaran bahasa Inggris.

Bahasa Inggris disebut sebagai Bahasa yang universal karena digunakan oleh sebagian besar negara di dunia sebagai bahasa utama. Bahasa Inggris juga merupakan salah satu Bahasa yang sangat

\footnotetext{
${ }^{7}$ HM.Hofi Anshari, Pengantar Ilmu Pendidikan (Surabaya: Usaha Nasional, 1993), 69.

8 Purwanto. Evaluasi Hasil Belajar. (Yogyakarta: Pustaka Pelajar, 2009), 45

${ }^{9}$ Umi Kusyairy, Sulkipli, meningkatkan hasil belajar peserta didik melalui pemberian reward and punishment Volume. 6 No. 2, September 2018, 84
} 
penting untuk dikuasai, terutama di era globalisasi. Beberapa negara bekas koloni Inggris menetapkan bahasa Inggris sebagai bahasa kedua yang wajib dikuasai setelah bahasa asli negara mereka. Berbeda dengan Indonesia yang menetapkan bahasa Inggris sebagai bahasa asing. Hal ini terlihat jelas dalam dunia pendidikan Indonesia. Bahasa Inggris mulai diajarkan dan dikenalkan pada peserta didik sejak tingkat Sekolah Dasar (SD) atau Madrasah Ibtidaiyah (MI) melalui kurikulum Pendidikan Dasar 1945.

Teknik pembelajaran bahasa Inggris di setiap daerah tentunya berbeda-beda. Hal teesebut yang kemudian mempengaruhi daya minat belajar terhadap pelajaran bahasa Inggris. Hal ini menjadi tantangan bagi guru bahasa Inggris. Perlunya inovasi yang terus berkembang dari guru agar peserta didik dapat terlibat secara aktif dalam proses pembelajaran. Persentase penggunaan bahasa Inggris di Indonesia masih ternilai sangat rendah, yakni dibawah delapan persen. Padahal bahasa Inggris dapat membawa nama Indonesia dikenal oleh dunia Internasional karena ada banyak potensi dan kekayaan yang dimiliki oleh Negara Indonesia, yang dapat dikomunikasikan dengan baik menggunakan Bahasa internasional tersebut.

Bahasa Inggris merupakan alat komunikasi yang mendominasi di seluruh dunia dikenal sebagai bahasa internasional. Bahasa Inggris juga menjadi bahasa ilmu pengetahuan dan teknologi, sehingga tanpa kemampuan bahasa Inggris seseorang akan mengalami kesulitan dalam perubahan pergaulan dunia. Kesadaran akan pentingnya penguasaan bahasa Inggris di era yang terus berkembang dibutuhkan upaya-upaya untuk mempelajari dan menguasai bahasa tersebut sejak sedini mungkin.

Selain itu, proses pembelajaran sangat diperlukan dengan strategi dan pendekatan yang tepat dan efektif. Kemampuan seorang guru dalam menyajikan proses kegiatan belajar mengajar yang menarik dan menyenangkan bagi anak menjadi hal yang berpengaruh keberhasilan pembelajaran bahasa Inggris terhadap anak. ${ }^{10}$ Oleh karena itu, bahasa Inggris sangat diperlukan oleh siswa di masa mendatang dalam menghadapi perubahan era yang terus berkembang. Dalam pembelajaran bahasa, siswa perlu mengetahui atau mengingat kosa kata dari bahasa tersebut. Sebagaimana yang dijelaskan dalam QS. Al- Baqarah ayat 31;

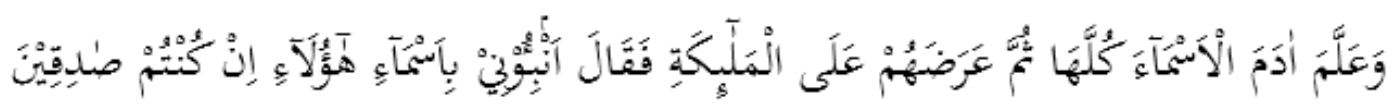

Artinya; 'Dia mengajarkan kepada Adam nama- nama (benda-benda) selurubnya, kemudian mengemukakannya kepada para Malaikat lalu berfirman; "Sebutkanlah kepada- Ku nama benda- benda itu jika kamu memang orang- orang yang benar!.” (QS. Al-Baqarah: 31).

10 Astien Liyana, Mozes Kurniawan, "Speaking Pyramid sebagai Media Pembelajaran Kosa Kata Bahasa Inggris Anak Usia 5- 6 Tahun”, 2019, 226. 
Berdasarkan ayat tersebut, ayat tersebut seakan disampaikan "jika kalian memang benar bahwa khalifah yang aku ciptakan di bumi itu akan melakukan kerusakan dan menumpahkan darah, maka kabarkanlah kalian kepada-Ku tentang nama-nama itu (yang kelak akan menjadi khalifah). Bagaimana kalian bisa mengaku tahu sesuatu yang belum ada, padahal kalian tak tahu apa yang kalian lihat dan kalian saksikan? Aku tak akan menciptakan khalifah jika kalian lebih tahu dan lebih baik darinya". ${ }^{11}$ Dari sini dapat dipahami bahwasanya sebelum mengetahui suatu bahasa, kita harus belajar mengetahui atau mengingat kosa kata tersebut agar menjadi orang yang berilmu dan memudahkan untuk melakukan komunikasi satu sama lain.

Sebelum penelitian ini, beberapa penelitian tentang metode Reward and Punishment sudah pernah dilakukan. Salah satunya pernah diteliti oleh Ima Melinda, dan Ratnawati Susanto dengan judul "Pengaruh Reward dan Punishment Terhadap Motivasi Belajar Siswa. Penelitian ini bertujuan untuk mengetahui ada tidaknya pengaruh yang signifikan antara pemberian reward and punishment terhadap motivasi belajar siswa kelas IV SDN Merak 1 Tangerang dan seberapa besar sumbangan pengaruh pemberian reward and punishment terhadap motivasi belajar tersebut. Penelitian ini merupakan penelitian kuantitatif.

Populasi penelitian adalah siswa kelas IV SDN Merak 1 Tangerang yang berjumlah 38 siswa. Teknik pengambilan sampel jenuh. Pengumpulan data dilakukan dengan menggunakan metode kuesioner (angket). Data hasil penelitian menunjukkan bahwa terdapat pengaruh yang signifikan antara kedisiplinan belajar terhadap motivasi belajar siswa kelas IV. ${ }^{12}$ Penelitian ini dapat membuktikan bahwasanya metode Reward dan Punishment mampu memberikan pengaruh yang signifikan terhadap motivasi belajar siswa. Oleh karena itu, peneliti akan melakukan penelitian dengan metode reward dan punishment terhadap salah satu lembaga di Bondowoso, yaitu Bintana Research and Literacy Shelter Indonesia (BRLS Indonesia).

BRLS Indonesia merupakan rumah literasi dan penelitian yang bertempat di Desa Grujugan Lor, Bondowoso, Jawa Timur. Lembaga ini diresmikan pada tanggal 11 Desember 2020 yang didirikan oleh Bintana Alin Hilwah, alumni prodi Tadris Matematika, IAIN Jember tahun 2019. Lembaga ini bertujuan menjadi tempat bagi para pecinta literasi mendalami dunia literasi dan penelitian. BRLS Indonesia telah menjadi tempat bimbingan penelitian secara offline atau online oleh beberapa peneliti atau mahasiswa semester akhir dari beberapa kampus di Indonesia. Selain itu, lembaga ini juga aktif menjadi tempat belajar adik- adik di sekitar lembaga BRLS Indonesia. Hal tersebut mampu membantu adik- adik memahami secara optimal tentang materi yang harus mereka kuasai

\footnotetext{
${ }^{11}$ Hasan Syaiful Rizal, “Hakikat Bahasa dan budaya Melalui Tinjauan Tafsir Al- Qur’an Surat Al- Baqarah: 31 - 33 , Ar Rahman: 1-4, dan Yusuf: 2”, 2021. 5

${ }_{12}$ Ima Melinda, Ratnawai Susanto, "Pengaruh Reward dan Punishment Terhadap Motivasi belajar Siswa" (International Jurnal of Elementary Education, 2018). 85
} 
selama pembelajaran daring atau offline hingga saat ini. BRLS Indonesia memiliki beberapa kegiatan seperti BRLS Talk, Macah Sastra, Research Discussion, Kunjungan, Webinar, dan lain sebagainya. ${ }^{13}$

Peneliti melakukan observasi ke BRLS Indonesia dan menemukan bahwa peserta didik BRLS Indonesia memiliki motivasi dan semangat yang tinggi untuk belajar. Mereka berumur sekitar 5 sampai 11 tahun. Namun, ketika peneliti meminta adik-adik BRLS Indonesia untuk menyebutkan kosa kata dan abjad bahasa Inggris, mereka merasa kesulitan dan enggan untuk belajar bahasa Inggris. Sedangkan, sesuai yang telah disampaikan diatas tentang pentingnya bahasa Inggris, bahasa Inggris perlu dipelajari sejak sedini mungkin. ${ }^{14}$

\section{METODE PENELITIAN}

Penelitian ini menggunakan pendekatan kualitatif deskriptif. Pendekatan kualitatif deskriptif adalah penelitian yang bertujuan memahami dan memaknai subjek serta memberikan semua gejala yang tampak, dan memaknai yang ada dibalik gejala. ${ }^{15}$ Peneliti berusaha memotret peristiwa dan kejadian yang menjadi pusat perhatiannya untuk dijabarkan atau digambarkan dalam bentuk data atau kalimat yang memberikan suatu penjelasan atau makna. Penelitian ini bukan untuk menguji teori, melainkan untuk menemukan proses pemberian reward dan punishment dalam peningkatan kosa kata bahasa Inggris di BRLS Indonesia. Penelitian ini seperti menguji hipotesis bahwa permasalahan yang menyatakan bahwa peserta didik BRLS Indonesia mengalami kesulitan dalam menyebutkan kosa kata dan abjad dalam bahasa Inggris.

Kehadiran peneliti dalam penelitian ini adalah guna mendapatkan data yang lebih lengkap dan menyajikan langsung di lapangan. Maka hal yang perlu dilakukan peneliti adalah sebagai berikut; 1. Melakukan observasi yang mendalam tentang latar penelitian.

2. Mengadakan wawancara secara langsung dengan informan (founder BRLS Indonesia) dan peserta didik.

Dalam teknik pengambilan sampel, peneliti menggunakan teknik pemberian reward dan punishment dalam pembelajaran kosa kata bahasa Inggris karena dengan adanya reward dan punishment akan menumbuhkan semangat belajar peserta didik. Selain itu, metode ini juga mampu menjadikan siswa untuk lebih aktif dan serius dalam penguasaan kosa kata dalam bahasa Inggris. Oleh sebab itu, pemberian reward dan punishment dijadikan satu pilihan dalam proses pencapaian tujuan dalam pembelajaran bahasa Inggris.

Sumber data dalam penelitian ini adalah subyek dari mana data dapat diperoleh. Data dapat diartikan sebagai fakta atau informasi yang didengar, diamati, dirasa, dan dipikirkan peneliti dari

\footnotetext{
13 Bintana Alin Hilwah, diwawancari oleh peneliti, Bondowoso 02 Agustus 2021.

14 Adik-adik BRLS Indonesia, diwawancarai oleh peneliti, Bondowoso 20 Agustus 2021.

${ }^{15}$ Nursapiah, Penelitian Kualitatif (Sumatera Utara: Wal Ashri Publishing, 2020$), 7$.
} 
sumber data di lokasi penelitian. Sumber data utama untuk penelitian kualitatif adalah tuturan dan perilaku, dan sisanya adalah data lain seperti dokumen. Oleh karena itu, beberapa sumber data yang digunakan dalam penelitian ini antara lain;

1. Data primer, yaitu data- data yang diperoleh dari sumber utama. Peneliti mengambil sumber data primer melalui wawancara. Sumber data tersebut yaitu founder Bintana Research and Literacy Shelter Indonesia.

2. Data sekunder, yaitu sumber data yang dikumpulkan, diolah, dan disediakan oleh pihak lain, tidak diterima secara langsung oleh peneliti dan subjek penelitian. Data sekunder meliputi dokumen resmi, buku, hasil penelitian berupa laporan, dan lain-lain. Sedangkan data yang dibutuhkan untuk penelitian ini meliputi buku-buku yang berkaitan dengan penelitian ini.

3. Jenis data ketiga, yaitu data pendukung yang memberikan penjelasan, penjelasan tentang sumber data utama dan tambahan, dan akan digunakan bila diperlukan.

Metode pengumpulan data yang dilakukan pada penelitian ini adalah sebagai berikut;

1. Satu jenis yaitu metode wawancara yang dilakukan untuk memperoleh informasi sehingga peserta akan berbagi pengalaman dengan peneliti, kemudian menulis ulang data yang direkam, kemudian melakukan ringkasan dan analisis.

2. Metode observasi yaitu mengumpulkan data sebanyak mungkin secara langsung dari tempat kejadian. Pengamatan berarti mengumpulkan data langsung dari lapangan. Data yang diamati dapat berupa gambaran sikap, tingkah laku, perilaku, tindakan, dan interaksi secara keseluruhan antar siswa. Pengamatan terlebih dahulu harus menentukan tempat yang akan diteliti, lalu menentukan sasaran yang akan diteliti.

Data yang terkumpul akan dianalisis dengan menggunakan teknik analisis deskriptif, artinya peneliti mencoba mendeskripsikan kembali data yang telah dikumpulkan. Sedangkan proses analisis data menggunakan proses analisis sebagai berikut;

1. Mengumpulkan data

Mengumpulkan data dilakukan melalui observasi, wawancara dan dokumentasi.

2. Reduksi data

Data yang telah direduksi memberikan gambaran yang tajam tentang hasil pengamatan dan permudah penulis untuk mencarinya, jika diperlukan suatu saat.

3. Penyajian data

Sekumpulan informasi tersusun yang memberikan kemungkinan adanya penarikan kesimpulan dan pengambilan tindakan dengan melakukan penyajian data yang diharapkan dapat memudahkan melakukan pemahaman terhadap masalah yang dihadapi sehingga kesimpulan yang diambil bukan kesimpulan yang gegabah atau terburu- buru. 


\section{Menarik Kesimpulan}

Hal ini merupakan proses yang terpenting dan terakhir dilakukan dalam analisis data kualitatif. Kesimpulan yan diambil dapat diuji kebenarannya dan kecocokannya sehingga menunjukkan keadaan yang sebenarnya.

Pengambilan data melalui tiga tahapan, yaitu pendahuluan, penyaringan, dan melengkapi data yang masih kurang. Jika terdapat data yang tidak relevan dan kurang memadai maka akan diadakan penelitian atau penyaringan data sekali lagi di lapangan, sehingga data tersebut memiliki kadar validitas yang tinggi.

Dalam penelitian, suatu teknik pemeriksaan keabsahan data yang memanfaatkan sesuatu yang lain diluar data untuk keperluan pengecekan atau sebagai pembanding data yang disebut triangulasi data. Triangulasi yang digunakan dalam penelitian ini adalah triangulasi sumber data, yaitu membandingkan dan mengecek ulang kepercayaan atas informasi yang diperoleh melalui waktu dan alat yang berbeda melalui metode kualitatif. Oleh sebab itu, pembanding yang digunakan dalam penelitian ini adalah observasi terhadap metode reward dan punishment dalam penguasaan kosa kata bahasa Inggris peserta didik BRLS Indonesia melalui wawancara kepada informan.

\section{PEMBAHASAN}

Profil Bintana Research and Literacy Shelter Indonesia

\section{Sejarah dan Tujuan BRLS Indonesia}

Bintana Research and Literacy Shelter Indonesia merupakan rumah literasi dan penelitian yang didirikan oleh Bintana Alin Hilwah, alumni Tadris Matematika, IAIN Jember tahun 2019. BRLS Indonesia bertempat di Grujugan Lor, Bondowoso dan diresmikan pada tanggal 11 Desember 2020. Tujuan didirikannya BRLS Indonesia adalah;

a. Sebagai wadah untuk pegiat literasi dan penelitian mendalami dunia literasi dan penelitian. Hal tersebut akan membantu mahasiswa semester akhir, penulis, dan orang yang ingin belajar tentang kepenulisan, penyusunan proposal atau skripsi, jurnal, dan lain sebagainya.

b. Sebagai tempat belajar adik-adik yang bertempat tinggal di sekitar BRLS Indonesia. Seperti yang kita pahami bersama, kita berada di situasi pandemi yang mengharuskan pendidikan dilaksanakan secara daring. Oleh sebab itu, ibu Bintana berkeinginan untuk membantu adikadik mendapatkan pemahaman secara optimal tentang materi yang harus dipelajari.

c. Sebagai lembaga yang mampu meningkatkan minat baca. Di BRLS Indonesia, ibu Bintana menyediakan pojok literasi yang berisi buku- buku yang bisa dibaca oleh adik- adik, volunteers, dan pengunjung BRLS Indonesia. Buku- buku tersebut terdiri dari buku dongeng, novel, ilmiah, dan lain sebagainya. 


\section{Keanggotaan BRLS Indonesia}

Ibu Bintana masih belum meresmikan keanggotaan BRLS Indonesia. Namun, ibu Bintana menerapkan system volunteers. Jadi, siapapun bisa bergabung, dan berpartisipasi dalam kegiatan BRLS Indonesia.

\section{Program Kerja}

Beberapa program yang secara konsisten dilaksanakan selama BRLS Indonesia didirikan. Program BRLS Indonesia adalah sebagai berikut;

a. Webinar

Agenda ini dilaksanakan 3 kali dalam setahun dengan topik yang berbeda. Webinar yang telah dilaksanakan sejak BRLS Indonesia berdiri adalah webinar tentang Pelatihan Penulisan Karya Ilmiah dan Publikasi Internasional pada bulan Oktober 2020, dan Webinar Feminisme Nasional pada bulan Maret 2021. Agenda ini selalu mengupayakan mengundang pemateri yang memang expert dibidangnya. Peserta webinar berasal dari kalangan umum, seperti tenaga kependidikan, pelajar, bahkan mahasiswa di seluruh Indonesia. Webinar diselenggarakan melalui aplikasi zoom meeting.

b. Research Discussion

Agenda ini merupakan agenda rutin dalam diskusi tentang penelitian. Agenda ini sebagai ruang dan tempat bimbingan untuk semua kalangan baik tenaga pendidik, mahasiswa semester akhir, pelajar, dan orang yang ingin mempelajari penelitian. Agenda ini memberikan pelayanan bimbingan tentang pembuatan matriks, proposal, skripsi, bahkan tesis.

c. Bincang Tiktok

Era komunikasi dan teknologi semakin berkembang, sehingga BRLS Indonesia pernah menyelenggarakan kegiatan bincang tiktok untuk memberikan edukasi bahwa aplikasi ini tidak hanya berisi tari. Namun, aplikasi ini berisi segala aspek kehidupan seperti pendidikan, ekonomi, lingkungan, dan lain sebagainya. Bincang Tiktok ini pernah diselenggarakan pada bulan Februari 2021 melalui aplikasi Instagram Live.

d. Kerjasama

BRLS Indonesia bercita- cita meningkatkan minat baca di Indonesia. Oleh karena itu, BRLS Indonesia pernah menandatangani MoU dengan Komunitas lentera SMP N 3 Bondowoso, Redaktur Majalah Pendidikan Al- Mashalih MAN Bondowoso, dan Mazda SMPN 2 Maesan Bondowoso.

e. Magang Online 
Magang online merupakan agenda untuk memberikan pelatihan kepada pelajar/ mahasiswa tentang mencari, dan menyalurkan bakat yang dimiliki dalam dunia media sosial, desain grafis, dan kepenulisan. Agenda ini berlangsung pada bulan Mei.

f. BRLS Talk

BRLS talk merupakan agenda berdiskusi tentang pengalaman pribadi yang bisa memotivasi dan memberikan inspirasi kepada penonton dalam mencapai sesuatu. Kegiatan ini dilaksanakan melalui aplikasi Instagram Live.

g. Nuzulul Qur'an

Nuzulul Qur'an merupakan agenda yang dilaksanakan di akhir bulan Ramadhan. Hal ini dimaksudkan untuk memperingati turunnya al- qur'an, dan tasyakuran. Agenda ini juga melaksanakan kegiatan ngaji puisi karya penulis yang memang expert dibidangnya, seperti karya Dhee Raj, dan lain sebagainya.

h. Kunjungan

BRLS Indonesia sudah dikenal oleh masyarakat. Sehingga, BRLS Indonesia sering dikunjungi oleh berbagai kalangan, seperti tenaga kependidikan, pelajar, mahasiswa, dan lain- lain. BRLS Indonesia juga sering dikunjungi oleh Kepala sekolah, bahkan mahasiswa yang berasal dari luar pulau Jawa.

i. Macah Sastra

Macah Sastra menjadi wadah bagi para pecinta sastra, seperti pantun, puisi, cerpen, dan lain sebagainya. Jadi, siapapun boleh mengirimkan karyanya melalui direct message aplikasi Instagram dan BRLS Indonesia akan post karya penulis di akun Instragram BRLS Indonesia @brls_indo dengan desain yang menarik.

j. Belajar Bareng

Kegiatan ini merupakan kegiatan rutin yang dilaksanakan hampir setiap hari oleh adik- adik yang bertempat tinggal di sekitar lembaga BRLS Indonesia untuk menyelesaikan pekerjaan rumah, belajar menghitung, membaca, dan lain sebagainya. ${ }^{16}$

\section{Hasil Penerapan Metode Reward dan Punishment terhadap Peningkatan Kosa Kata Ba- hasa Inggris di BRLS Indonesia.}

Hasil penerapan metode reward dan punishment dalam penguasaan kosa kata adik- adik BRLS Indonesia. Berdasarkan data yang terkumpul, peneliti dapat menarik kesimpulan penerapan metode reward dan punishment dalam penguasaan kosa kata peserta didik di BRLS Indonesia, adalah;

\footnotetext{
${ }^{16}$ Bintana Alin Hilwah, diwawancarai oleh peneliti, Bondowoso, 20 Agustus 2021.
} 
1. Adanya peningkatan setelah penerapan metode reward dan punishment. Peningkatan tersebut ditemukan ketika peneliti menerapkan metode reward dan punishment dalam pembelajaran kosa kata bahasa Inggris dalam setiap pertemuan. Pertemuan pertama, peneliti mencoba beradaptasi dengan pola pikir, sifat/ sikap, dan kebiasaan peserta didik BRLS Indonesia agar memudahkan untuk proses kegiatan belajar mengajar. Peneliti menemukan bahwa mereka sangat berantusias dalam belajar, namun ketika peneliti meminta membaca abjad dan menyebutkan kosa kata bahasa Inggris, mereka mengalami kesulitan. Hal tersebut sesuai dengan yang telah disampaikan oleh pendiri BRLS Indonesia yang mengatakan bahwa "Adik-adik memang kesulitan dalam pengucapan abjad dan kosa kata dalam bahasa Inggris, karna mereka lebih tertarik membaca buku dongeng yang saya sediakan dan tugas tematik dari sekolahnya". ${ }^{17}$

Pertemuan kedua, peneliti memberikan penjelasan kepada adik- adik tentang cara pembacaan abjad dalam bahasa Inggris. Peneliti menemukan bahwa di awal pembelajaran, adikadik sangat berantusias untuk belajar bahasa Inggris, namun mereka merasa bosan setelah membaca berulang- ulang abjad bahasa Inggris. Hal tersebut sesuai dengan yang disampaikan oleh pendiri BRLS Indonesia yang mengatakan bahwa "Adik-adik itu masih memiliki hobi main. Jadi kalau diajak serius terus, mereka akan bosan. Oleh karena itu, silabkan implementasikan metode pembelajaran untuk membuat suasana kelas lebih menyenangkan". 18

Sehingga, peneliti mengimplementasikan metode reward dan punishment. Reward berupa tepuk tangan dan pujian bagi yang bisa mengulang bacaan abjad bahasa Inggris dengan benarr. Punishment berupa mengulang bacaannya hingga mereka bisa. Dalam penerapan metode ini, peneliti juga kombinasikan dengan gerakan tepuk tangan, dan lagu kepala pundak lutut kaki agar kelas lebih hidup dan memberikan suasana yang menyenangkan. Dalam pertemuan ini, adik- adik sudah mampu membaca abjad dalam bahasa Inggris dan beberapa kosa kata dalam bahasa Inggris seperti table, chair, lamp, cable, book, dan lain sebagainyya.

Pertemuan ketiga, peneliti memberikan kosa kata baru seperti window, wall, door, floor, roof, dan benda di sekitar adik-adik BRLS Indonesia. Pertemuan ini, peneliti juga kombinasikan dengan lagu kepala pundak lutut kaki, gerakan tepuk tangan, dan lagu marina menari. Metode reward dan punishment tetap diterapkan. Jika adik- adik BRLS Indonesia salah gerakan ketika pundak lutut kaki, gerakan tepuk tangan, dan lagu marina menari, sebagai punishment mereka harus berdiri dan mengulang materi yang sudah dipelajari seperti membaca abjad bahasa Inggris, dan menyebutkan kosa kata yang telah dipelajari.

17 Ibid

${ }^{18}$ Bintana Alin Hilwah, diwawancarai oleh peneliti, Bondowoso, 21 Agustus 2021. 
Sebagai reward, adik-adik yang benar gerakannya, mereka diperbolehkan menanyakan bahasa Inggris suatu benda yang pernah dipelajari kepada temannya yang mendapatkan punishment atau hukuman. Peneliti juga menemukan bahwa selama tiga pertemuan belajar bareng dengan adik-adik BRLS Indonesia, secara tidak langsung mereka dilatih untuk bertanggungjawab dengan konsekuensi yang diterima. Hal ini sangat sesuai dengan yang dikatakan pendiri BRLS Indonesia bahwa "Penerapan metode reward dan punishment memberikan dampak yang positif bagi adikadik BRLS Indonesia seperti meningkatnya kosa kata bahasa Inggris, melatih kedisiplinan, dan rasa tanggungjawab dengan diri sendiri". 19

\section{Tingkat Keyakinan dan Kepuasan Peserta Didik dalam Menguasai Kosa Kata Bahasa} Inggris

Peneliti menemukan poin kedua ini dalam pertemuan keempat belajar bareng dengan adik- adik BRLS Indonesia. Pada saat itu, peneliti menjelaskan beberapa nama hewan dalam bahasa Inggris. Metode reward dan punishment tetap diterapkan dan dikombinasikan dengan permainan tebak hewan agar tidak membosankan. Adik- adik BRLS Indonesia dibagi menjadi dua kelompok, mereka diberikan dua sampai 3 kata hewan dalam bahasa Inggris, lalu salah satu dari mereka meragakan hewan tersebut dan teman yang lain harus menebak hewan itu hingga benar. Dia yang cepat menyelesaikan tebak hewan tersebut, mereka akan mendapatkan pujian, tepuk tangan, dan poin sebagai reward. Mereka yang kalah akan mendapatkan skor 0 sebagai punishment.

Diakhir pembelajaran, ibu Bintana menyediakan beberapa hadiah berupa kerajinan tangan. Reward ini akan diberikan kepada mereka yang bisa menyebutkan kosa kata yang telah dipelajari selama belajar bareng dan abjad bahasa Inggris. Bagi yang tidak bisa menyebutkan kosa kata dan bacaan abjad bahasa Inggris, mereka tidak akan mendapatkan hadiah kerajinan tangan tersebut (punishment).

Para peserta didik memiliki tingkat keyakinan yang tinggi untuk mencoba menjawab pertanyaan peneliti. Mereka menyebutkan kosa kata dan abjad bahasa Inggris dengan jelas tanpa ada rasa ragu. Selain itu, usai mendapatkan hadiah, mereka merasakan kepuasaan dengan hadiah yang didapat. Mereka juga memiliki rasa ingin belajar lebih giat dalam bahasa Inggris. Sebagaimana yang disampaikan oleh pendiri BRLS Indonesia bahwa "saya merasa bangga, ketika adik-adik bisa dengan percaya dirinya menunjuk.kan bahwa mereka bisa menyebutkan kosa kata dan abjad dalam bahasa Inggris". ${ }^{20}$

\footnotetext{
${ }_{19}$ Bintana Alin Hilwah, diwawancarai oleh peneliti, Bondowoso, 29 Agustus 2021.

${ }^{20}$ Bintana Alin Hilwah, diwawancarai oleh peneliti, Bondowoso, 30 Agustus 2021.
} 
Implementasi Reward Dan Punishment Terhadap Peningkatan Kosa Kata Bahasa

\section{Menentukan perbuatan yang harus dilakukan.}

Penerapan metode reward dan punishment kepada adik-adik BRLS Indonesia membuat sebelumnya sukar untuk menguasai kosa kata bahasa Inggris menjadi lebih mudah dalam menguasai kosa kata bahasa Inggris.

"Hasil penerapan metode reward dan punishment ini dilihat dari pertanyaan yang diajukan kepada adik-adik BRLS Indonesia. Seelumnya, mereka kesulitan dalam membaca abjad bahasa Inggris, namun sekarang mereka dengan mudah membaca abjad bahkan mengingat 20 kosa kata bahasa Inggris". 21

Adik- adik BRLS Indonesia yang sudah mengalami peningkatan dalam menguasai kosa kata bahasa Inggris masih perlu diamati agar mereka bisa menambah pemahaman kosa kata dalam bahasa Inggris lebih baik. Karena tugas dari seorang pendidik harus memberikan bimbingan yang optimal untuk masa depan yang lebih baik. Sedangkan adik- adik yang masih malas untuk belajar bahasa Inggris, pendidik harus selalu memberikan dorongan kepada mereka untuk terus semangat dan sukses dalam belajar.

\section{SIMPULAN}

Penerapan metode reward dan punishment terhadap peningkatan kosa kata bahasa Inggris adik- adik BRLS Indonesia. Mereka menjadi sangat antusias dalam proses kegiatan belajar mengajar. Metode rewsard dan punishment yang dikombinasikan dengan beberapa permainan dan gerakan seperti gerakan tepuk tangan, marina menari, kepala pundak lutut kaki, dan tebak hewan memotivasi adikadik untuk menguasai kosa kata bahasa Inggris. Reward bisa berupa skor, pujian, tepuk tangan, dan hadiah kerajinan tangan. Sedangkan punishment bisa berupa adik- adik mengulang yang sudah dipelajari, tidak mendapatkan skor, atau bahkan tidak mendapatkan hadiah kerajinan tangan. Namun, sebagai pendidik seharusnya tidak memberikan hukuman fisik, tetapi harus memberikan treatment agar siswa bertanggungjawab atas tugasnya.

Kelebihan dari metode ini adalah menumbuhkan rasa kompetitif, dan memotivasi belajar siswa secara maksimal. Sedangkan kekurangan dari metode ini adalah membutuhkan biaya lebih sebagai hadiah, terkadang menjadi beban bagi pemalas yang memiliki mental lemah, dan terfokuskan pada siswa yang aktif. Berdasarkan data yang terkumpul disimpulkan tingkat penguasaan kosa kata bahasa Inggris dalam pembelajaran meningkat disertai tingkat keyakinan dan kepuasan siswa dalam proses pembelajaran.

\section{DAFTAR PUSTAKA}

Anshari, Hofi. Pengantar Ilmu Pendidikan, Surabaya: Usaha Nasional, 1993.

\footnotetext{
${ }^{21}$ Ibid
} 
Arikunto, Suharsimi. Penelitian Tindakan Kelas. Jakarta: Bumi Aksara, 2006.

Asmawati, Maisah, dkk, "Pemberian Reward dan Punishment Terbadap Motivasi Belajar Siswa pada Muatan PPKN Kelas IV SDN Pemepek Kecamatan Pringgarata Tabun Ajaran ～2020/2021”, Jurnal Inovasi Penelitian, Universitas Mataram, 2020.

Ima Melinda, Ratnawai Susanto, "Pengaruh Reward dan Punishment Terbadap Motivasi belajar Siswa", International Jurnal of Elementary Education, 2018.

Kusyairy, Umi, Sulkipli, meningkatkan hasil belajar peserta didik melalui pemberian reward and punishment Volume. 6 No. 2, September 2018

Liyana, Astien, dan Kurniawan, Mozes. "Speaking Pyramid sebagai Media Pembelajaran Kosa Kata Bahasa Inggris Anak Usia 5- 6 Tahun”, 2019.

Nursapiah, Penelitian Kualitatif, Sumatera Utara: Wal Ashri Publishing, 2020.

Purwanto. Evaluasi Hasil Belajar. Yogyakarta: Pustaka Pelajar, 2009.

Sujana, Nana. Penelitian hasil proses belajar mengajar. Bandung: PT. Remaja Rosdakarya. 2005.

Sutikno, M. S. Belajar dan Pembelajaran, Prospect. Bandung. 2009.

Syaiful Rizal, Hasan, "Hakikat Babasa dan budaya Melalui Tinjanan Tafsir Al-Qur'an Surat Al-Baqarab: 31- 33, Ar Rahman: 14, dan Yusuf: 2", 2021.

Yunus dan Hasyim Fanirin, Moch., "Penerapan Metode Reward and Punishment dalam Penguasaan Kosakata Bahasa Arab Kelas IV Madrasah Diniyah Takmiliyah Awaliyah Haurkolot, Indramayu", Jurnal Pendidikan Indonesia, Institut Agama Islam Al Zaytun Indonesia, 2021.

\section{Wawancara}

Alin Hilwah, Bintana, founder BRLS Indonesia

Peserta Didik di BRLS Indonesia 
Implementasi Reward Dan Punishment Terhadap Peningkatan Kosa Kata Bahasa

248 | FENOMENA, Vol. 20 No. 2 (Juli - Desember 2021) 